\title{
MEMAHAMI PLURALISME
}

\author{
Oleh: DR Kuntjoro Tjondro ${ }^{1}$
}

\begin{abstract}
The idea of pluralism is developing of religious thought, arises by influenced of development of cultural thought, ideology, certain interests, and the power interest. Also the situation of new religions, enter and meet the old religion. At the first, religion is generally exclusivist, but tolerance interest develop it to be inclusive, and finally pluralist, so does for Christianity, as well as other religions. There is truth in each religion, itsmust be respected, but righteous and savetyjust only in its own religion and belief. The real pluralism rejects the notion of every religion can bring its followers to heaven or to save.
\end{abstract}

Keywords: pluralism, religion, truth, save, interest

\section{Pengantar}

Pluralisme Agama merupakan pandangan yang mengatakan bahwa di dalam agama-agama terdapat kebenaran-kebenaran yang dapat meyelamatkan. Allah memberikan wahyuNya kepada bangsa-bangsa melalui masing-masing nabiNya untuk menyatakan kebenaran kepada mereka. Seperti, kepada orang Yahudi, kepada orang Arab, kepada orang India, kepada orang China, kepada orang-orang Kristen, dan seterusnya, masing-masing ada tokoh agama yang mengajarkan

\footnotetext{
${ }^{1}$ Penulis adalah Ketua Prodi Magister Teologi di STT Nazarene Indonesia
} 
kebenaran-kebenaran Allah. Dengan demikian setiap agama memiliki kebenaran yang dapat menyelamatkan dan wajib untuk dihormati. Masing-masing agama mengajarkan kebenaran yang sesuai dengan bangsa/suku serta budaya mereka masing-masing. Tidak perlu orang bersikukuh dan menyatakan bahwa agamanya yang paling benar dan yang lain adalah salah. Namun pluralisme yang diikuti oleh agama-agama di Indonesia (Islam, Kristen, Hindu, Buddha) tidak demikian. Mereka meyakini tentang kebenaran yang ada dalam setiap agama, namun kebenarankebenaran yang ada dalam setiap agama masing-masing tersebut tidak mampu untuk menyelamatkan, dan hanya kebenaran yang ada dalam agama keyakinannya saja yang mampu menyelamatkan atau membawa jiwanya ke sorga. ${ }^{2}$

Pluralisme ini sebenarnya tidak terbatas pada keselamatan saja (semua agama dapat membawa umatnya untuk masuk dalam keselamatan), tetapi juga berkaitan dengan sikap hidup yang penuh dengan toleransi. Dalam hal ini pluralisme sangat toleran terhadap sikap hidup orang lain sehingga tanpa perduli atau tutup mulut jika melihat hal-hal yang bersikap amoral. Indonesia yang memiliki keaneragaman dan keyakinan, suku, bahasa, budaya, sosial harus dianggap sebagai anugrah Tuhan secara khusus, karena dengan keberagaman tersebut terwujud negara Indonesia. Dahulunya tidak ada negara Indonesia sebelum kemerdekaannya 1945, namun karena sesatuan, satu tanah air, satu bangsa, satu bahasa, sehingga akhirnya terwujud negara Indonesia yang majemuk ini. Itulah sebabnya toleransi ini perlu dijaga dan dipelihara secara baik dan adil. ${ }^{3}$

Sebagai orang Injili yang menekankan ajaran yang sesuai dengan Alkitab, dan berpandangan bahwa kekristenan bersifat "eklusivisme", yaitu kekristenan adalah suatu agama/keyakinan yang unik, karena hanya di dalam kekristenan terdapat ajaran kebenaran yang

\footnotetext{
${ }^{2}$ M. Amin Abdullah, Kebebasan Beragama atau Dialog Antar-Agama, dalam J.B. Banawiratma, dkk, Hak Asasi Manusia Tantangan bagi Agama, (Yogyakarta: Kanisius, 1999), hlm. 58-59.

${ }^{3}$ A.A. Yewangoe, Agama dan Kerukunan, (Jakarta: BPK Gunung Mulia, 2011), hlm. 71-75.
} 
dapat menyelamatkan jiwa manusia dari hukuman dosa. Yesus Kristus adalah satu-satunya Juruselamat yang dapat menyelamatkan dan di luar Dia tidak ada jalan keselamatan. Di luar agama Kristen tidak ada keselamatan, kebenaran memang ada tetapi kebenaran tersebut tidak mampu untuk menyelamatkan manusia dari dosanya. Pernyataan Alkitab sangat jelas dan tidak diragukan lagi: Yoh 14:6; Kisah 4:16; dan lain-lain. Jikalau orang ingin diselamatkan, tidak ada cara lain kecuali percaya kepada Yesus Kristus sebagai Juruselamat, dan mengikuti kehidupan sesuai dengan kaidah-kaidah yang sesuai dengan Alkitab sebagai firman Allah. ${ }^{4}$ Tentu saja eklusivisme ini tidak hanya ada di kekristenan tetapi ada juga pada agama-agama lain, seperti agama Islam, agama Hindu, agama Budha. ${ }^{5}$

Dari segi konsep keselamatan pandangan kaum injili (kita) cukuplah jelas dan tegas yang menolak pandangan pluralisme karena pluralisme berpendapat bahwa dalam agama apapun para pemeluknya bisa mendapatkan keselamatan. Namun sebagai orang yang hidup di tengah-tengah masyarakat yang pluralis tentunya memiliki sikap yang bijak dan memuliakan nama Allah. Oleh sebab itu perlu memahami sejarah teologi agama-agama sehingga sikap bijak dan memuliakan Allah tersebut dapat diwujudkan. Dalam teologi agama-agama umumnya membicarakan tentang eklusivisme, inklusivisme, dan pluralisme.

\section{Eklusivisme}

4

- Tuhan Yesus memang Khas Unik, terj: Lilian Tedjasudhana, (Jakarta: Yayasan Komunikasi Bina Kasih/OMF, tt), hlm. 21-24. Cavin D'Costa (penyunting) juga membicarakan tentang Kristus dan Agama-agama dalam bukunya Mempertimbangkan Kembali Keunikan Agama Kristen, (Jakarta: BPK Gunung Mulia, 2009), hlm. 97-116.

${ }^{5}$ Horald Coward, Pluralisme Tantangan bagi Agama-agama, (Yogyakarta: Penerbit Kanisius, 1989), hlm. 87-165. Penulis Islam Mohammad Hassan Khalil secara tegas mengungkapkan bahwa pemeluk agama Kristen tidak dapat masuk sorga karena dosa "syrik" menyatakan Yesus sebagai Tuhan, Islam dan Keselamatan Pemeluk Agama Lain, (Bandung: Mizan Media Utama, 2016), hlm. 55. 
Pandangan ini menyatakan bahwa, jika Yesus Kristus secara unik adalah kebenaran, dan satu-satunya jalan keselamatan bagi umat manusia, itu berarti bahwa agama-agama lain itu tidak benar dan bahwa agama-agama lain itu tidak merupakan jalan keselamatan. ${ }^{6}$ Satu catatan yang harus diingat bahwa kata eksklusivisme ini tidak dipakai dalam arti pribadi, sikap atau sosial, yakni dengan menyisihkan orang lain. Kata ini hanya berkaitan dengan cara menemukan kebenaran keselamatan.

\section{Dasar pemikiran dari eksklusivisme ini adalah: ${ }^{7}$}

Pertama, manusia telah jatuh ke dalam dosa dan tersingkir dari hadirat Allah secara radikal (kejatuhan total), sehingga mustahil mampu menyelamatkan diri sendiri atau mengenal Allah secara benar dengan kemampuan sendiri.

Kedua, Allah berprakarsa dan bertindak memperkenalkan diri-Nya dan menyelamatkan umat manusia, dengan cara yang unik sepanjang sejarah Israel sejak Abraham dengan maksud mendatangkan berkat bagi bangsa-bangsa.

Ketiga, Yesus dari Nazaret adalah khas unik, satu kali dan untuk selamanya, inkarnasi Allah dalam manusia. Dia adalah perwujudan dari Allah, dan telah menyelesaikan tuntas karya penyelamatan Allah di kayu salib. Melalui kebangkitan-Nya dan kenaikan-Nya ke sorga, Allah telah mengesahkan Yesus sebagai Tuhan dan karena itu benarlah jika Ia disembah sebagai Tuhan.

Keempat, keselamatan hanya dapat diperoleh dalam dan melalui Yesus Kristus. Penganut agama lain, sama seperti manusia, diciptakan dalam gambar dan rupa Allah dan ikut menikmati

\footnotetext{
6 -----------------, Tuhan Yesus memang Khas Unik, terj: Lilian Tedjasudhana, (Jakarta: Yayasan Komunikasi Bina Kasih/OMF, tt), hlm. 17.

${ }^{7}$ Ibid. 17-18.
} 
berkat penyataan secara umum dalam hati nuraninya dan alam semesta. Tapi pada hakikatnya keselamatan hanya diperoleh dalam Kristus.

Kelima, ada ketidak sinambungan radikal antara agama-agama lain dan penyataan dan penyelamatan Allah dalam Kristus. Yaitu, Allah telah melakukan dalam Kristus apa yang tidak Dia lakukan dalam konteks agama-agama lain. Ada perbedaan esensial antara penyataan serta penyelamatan alkitabiah dan agama-agama lain.

Eksklusivisme biasanya dikaitkan dengan pandangan injili konservatif atau fundamentalis. Karl Bart sebagai tokoh Neo-Ortodok dengan gigihnya memberikan penegasan tentang pandangan eksklusivis ini. Dalam argumennya mengungkapkan bahwa Allah hanya bisa dikenal di dasarkan atas Kristus, dan semua iman lainnya, yang tidak di dasarkan atas Kristus, adalah ketidakpercayaan menurut definisi dan asumsi. Bahkan kekristenan, sebagai agama manusia, tegasnya, bisa setiap saat menjadi suatu bentuk ketidakpercayaan apabila penganutnya tidak lagi hidup hanya oleh kasih karunia Kristus. ${ }^{8}$

\section{Inklusivisme}

Inklusivisme memberikan argumen, bahwa pada akhirnya segala kebenaran dan kebenaran Allah, dan karena itu Kristus harus mencakup semua yang benar dalam agama lain. ${ }^{9}$ Segala kebenaran dan kebaikan berasal dari Allah, dan karena itu juga dengan satu atau lain cara harus berasal dari dan melalui Kristus. Jadi kebenaran atau kebaikan apapun yang dapat kita lihat dalam agama lain, harus dihubungkan dengan Kristus yang dengan satu atau lain cara berada dan bekerja di dalam diri penganut agama tersebut. Dalam inklusivisme ini agama Kristen

\footnotetext{
${ }^{8}$ Paul Enns, The Moody Handbook Of Theology, terj: Rahmiati Tanudjaja, (Malang: Literatur SAAT, 2007), hlm. 214-215.

9 -------------, Tuhan Yesus memang Khas Unik, terj: Lilian Tedjasudhana, (Jakarta: Yayasan Komunikasi Bina Kasih/OMF, tt), hlm. 23.
} 
merupakan pemenuhan apa yang dicari, atau tersembunyi, atau sedang diupayakan dalam agamaagama lain.

\section{Dua bentuk inklusivisme yang banyak dikenal adalah:}

Pertama, ada yang mengatakan tentang agama lain, secara garis besar, "Penyataan - Ya!, tapi Keselaman - Tidak”. Maksudnya, mereka setuju bahwa ada penyataan umum yang universal bagi segenap umat manusia. Dengan demikian mereka bisa memberikan persetujuan terbatas pada agama-agama lain karena adanya unsur-unsur penyataan umum, bahkan sampai tingkat tertentu mengakui adanya penyusupan Iblis dan kebobrokan manusia yang bisa ditemukan dalam semua agama (termasuk Kristen sebagai agama). Tetapi mereka menyangkal bahwa ada karya keselamatan Allah dalam agama lain. Inklusiv jenis ini tidak menerima bahwa Allah menyelamatkan melalui agama-agama lain itu. Jadi Kristus tetap sebagai sentral dan asasi untuk penyelamatan, tetapi agama lain bisa menolong untuk membuat persiapan bagi Kristus, atau bahkan menjadi perantara untuk kasih karunia Allah yang terwujud penuh dalam Kristus.

Kedua, meskipun agama Kristen tetap merupakan kebenaran yang tertinggi danterunggul, agama non-Kristen bisa mencakup unsur-unsur kasih karunia supernatural bagi seseorang (sampai datangnya Injil) sebagaihadiah gratis dari Allah karena Kristus. Pandangan ini diajukan oleh Karl Rahner yang merupakan pakar utama teologi Katolik Roma dalam bidang agama lain. Dia berpendapat bahwa agama lain dapat menjadi sarana positif untuk mendapatkan hubungan yang benar dengan Allah dan dengan demikian untuk memperoleh keselamatan. ${ }^{10}$

Penting untuk disadari bahwa kasih karunia seperti yang dilihat Rahner dalam agamaagama lain, selalu adalah kasih karunia yang didapatkan melalui Yesus Kristus. Jadi ia

\footnotetext{
${ }^{10}$ Ibid. hlm. 24-25.
} 
menganggap orang-orang non Kristen yang tulus sebagai “Kristen anonim” melalui kasih karunia, yang telah mereka terima secara tidak sengaja melalui agama mereka masing-masing. Jadi orang dapat diselamatkan oleh kasih karunia Allah melalui Kristus tanpa masuk menjadi umat Kristen. Sebagai contah: Orang Islam yang baik dan kemudian dan diakui, misalnya, diselamatkan oleh Kristus melalui rukun Islam. Sesungguhnya dia adalah seorang "Kristen anonim." 11

Tentang kekristenan anonim ini, Rahner mengungkapkan bahwa sering menjadi pokok perdebatan dan kritik. Banyak pengecamnya mengatakan bahwa sikap itu memandang rendah orang-orang beragama lain.

Jadi inklusivisme ini berusaha untuk mempertahankan keunikan dan kesentralan Kristus, namun menggeser fokusnya dari pandangan eksklusif tentang Kristus ke pandangan yang lebih universal tentang Allah dan tindakan-Nya di dalam dan melalui agama-agama lain.

\section{Pluralisme}

Seliberal-liberalnya seorang teolog dan cendekiawan Kristen mereka masih berpendirian dan berpandangan "Kristosentris". Maksudnya mereka ingin mempertahankan sentralisasi Kristus sendiri (baik dalam arti eksklusif maupun inklusif). Kristus adalah pusat dan standar (norma) bagi semua agama lain. Tapi baru-baru ini beberapa teolog radikal melangkah lebih jauh dan memperjuangkan apa yang mereka sebut teologi agama-agama yang teosentris. Jadi mereka ingin menempatkan Allah (theos) di pusat jagat agama, bukan Kristus atau kekristenan.

Ini bukan semata-mata sinkritisme. Sinkritisme adalah keinginan untuk membaurkan dan menyatukan yang terbaik dari semua agama dunia sehingga menjadi satu gabungan agama dunia untuk masa depan. ${ }^{12}$ Sinkritisme merupakan agama pilih campur. Diasumsikan bahwa ada bagian-

\footnotetext{
${ }^{11}$ Ibid, hlm. 25.

${ }^{12}$ Ibid, hlm. 29.
} 
bagian dari beberapa agama yang harus ditolak, sementara unsur-unsur yang cocok satu sama lain harus dipertahankan.

Sebaliknya pluralisme merasa puas untuk menganggap semua agama secara utuh, sah dan saling melengkapi. Ini merupakan tanggapan yang berbeda terhadap apa yang sering disebut “realitas ilahi terunggul". Bahkan pertentangan yang nampak antara agama yang berbeda, bisa dilihat hanya sebagai akibat keterbatasan manusiawi kita (kita sama sekali tidak mungkin menjangkau seluruh kebenaran). Jadi kita tidak perlu berusaha menyelesaikan pertentanganpertentangan itu. Meskipun keyakinan satu agama sama sekali bertentangan dengan agama-agama lain, kita tidak perlu memutuskan mana yang benar dan mana yang salah, karena semuanya bisa benar pada suatu tingkatan realitas yang lebih dalam yang belum kita pahami.

\section{Munculnya Pluralisme Modern}

Ide tentang Pluralisme bermula dari pemikiran Bapa gereja yang mula-mula yang mengalami penyimpangan, yaitu Clement dan Origens. Clement mengatakan bahwa pengenalan akan Allah bagi orang Yahudi adalah melalui Taurat, sedangkan bagi orang Yunani melalui filsafat dalam inspirasi Logos (Kristus). Sedangkan Origens mengatakan bahwa pada akhirnya, semua mahluk akan diselamatkan termasuk setan. Pernyataan ini merupakan akar dari universalisme sekaligus sebagai akar dari Pluralisme. ${ }^{13}$

Paham ini kemudian terus berkembang setelah reformasi dan setelah jaman pencerahan. Dua orang teolog Jerman yang beraliran Pietisme yang radikal yaitu Johanes Wilhem Peterson dan Ernest Christoph Hockman mengajarkan mengenai pemulihan akhir dari jiwa-jiwa kepada Allah.

\footnotetext{
${ }^{13}$ Horald Coward, Pluralisme Tantangan bagi Agama-agama, (Yogyakarta: Penerbit Kanisius, 1989), hlm.
} 44. 
Pandangan Universal ini akhirnya berkembang di Amerika, dan tokoh yang paling terkenal berkenaan dengan ini yaitu Friedrich Schleiermacher (1768-1834). Agama Kristen hanyalah salah satu agama yang memiliki keselamatan sebagaimana agama yang lain juga. Kasih Allah yang besar menurut mereka tidak akan mengirim seorangpun kedalam neraka untuk menghadapi penghukuman kekal. ${ }^{14}$

Munculnya gerakan untuk memberantas penderitaan manusia dan bangkitnya kembali agama-agama tradisional juga membawa pengaruh besar bagi dunia theologi. John AT Robinson merupakan salah satu teolog universalis dari Inggris yang terkenal dengan pikirannya yang radikal mengenalkan teologi sekularisasi, dimana kasih Allah dijadikan kunci teologi sekularisasinya, dan menegaskan hakekat kasih Allah yang maha kuasa adalah menjamin keselamatan semua manusia di dunia ini. John Hick, seorang pelopor utama Pluralisme, mengubah posisinya yang tadinya berdasarkan pada keadilan Allah, menjadi posisi yangmendasarkan pada kasih Allah, dimana baginya penderitaan dan kejahatan manusia ini dapat dibenarkan jika Allah dapat membawa manusia kepada pemulihan akhir setiap manusia. ${ }^{15}$

Hal lain yang menjadi pemicu kemunculan ide Pluralisme adalah perkembangan filsafat terutama filsafat agama dan ketuhanan. Pemikiran-pemikiran para fisuf dan teolog yang tidak lahir baru membawa paradigmaparadigma dalam arus pemikiran teologi. Tokoh-tokoh yang membawa pengaruh yang cukup besar yaitu; Rene Descartes, Benedict Spinoza, Thomas Aquinas, Imanuel Kant, Bertrand Russel, William James, John Locke, David Hume, Karl Barth, Emil Bruner, dan masih banyak lagi tokoh yang mempertanyakan kembali pemahaman kebenaran ketuhanan dalam agama Kristen yang sudah baku. ${ }^{16}$

\footnotetext{
${ }^{14}$ Ibid. hlm. 48-49.

15 Ibid. hlm. 57-58.

16 Ibid. hlm. 64.
} 
Dan salah satu tokoh yang membawa ide utama tentang Pluralisme adalah Ernst Troeltsch.Ernst Troeltsch yang hidup di Jerman antara 1865-1923 adalah seorang teolog yang boleh dikata sangat memberi inspirasi bagi perkembangan teologi kekinian yang berbicara tentang Pluralisme.

\section{Relativisme Sebagai Salah Satu Titik Tolak Pluralisme Modern}

Berbicara tentang perkembangan Pluralisme modern, maka hal tersebut tidak terlepas dari masalah relativisme. Dan bila kita membahas tentang Pluralisme, kita juga harus melihat kepada Eksistensialisme dan Pragmatisme. Relativisme yang tidak terlepas dari filsafat Eksistensialisme, yang dikemukakan pertama sekali oleh Immanuel Kant, yang juga sering disebut sebagai seorang filsuf pencerahan. Salah satu pemikiran Kant adalah, bahwa ia menolak setiap usaha untuk mengklaim suatu bentuk absolut yang berusaha bebas dari pengalaman, dan tekanannya pada keunggulan budi telah melampaui pengaruh hebat terhadap pemikiran barat. Eksistensialisme adalah usaha untuk membangun sistem filsafat yang berangkat dari titik tolak manusia sebagai pembuat dan penentu atas pemikiran dan segala sesuatu yang beredar dalam lingkaran kehidupan ini. Pemeluk Eksistensialisme percaya bahwa manusia memiliki kapasitas eksistensi yang potensial dalam kehidupannya. ${ }^{17}$

Bagi orang Pragmatis, kebenaran bukanlah ide yang pasti yang kita usahakan untuk menemukannya, tetapi kebenaran adalah sesuatu yang terjadi dengan suatu ide. Dan ini sama persis dengan teori evolusi. Mereka melihat kebenaran dari perspektif waktu, yang akhirnya berakhir kepada kesimpulan bahwa kebenaran itu sendiripun bersifat relatif. Bila kebenaran bersifat relatif maka bila hal ini diterapkan kepada agama berarti suatu agama tidak boleh dinilai untuk dirinya

${ }^{17}$ Linda Smith dan William Raeper, Ide-ide Filsafat dan Agama Dulu dan Sekarang, (Yogyakarta: Penerbit Kanisius, 2000), hlm. 76-78. 
sendiri, tetapi demi akibat-akibat moral dan psikologis. William James salah satu pelopor fiosofi Pragmatis menulis; "Bila hipotesis mengenai Allah berhasil secara memuaskan dalam arti kata yang paling luas, maka hipotesis itu benar." 18

Kedua pandangan diatas merupakan dasar dari paham relativisme. Relativisme mengklaim bahwa keberagaman yang ada pada suatu waktu, tempat dan orang kepada yang lain, itu bergantung pada kondisi yang berubah. Hal inilah yang menyebabkan bahwa tidak ada kebenaran yang universal, yang valid untuk semua orang disegala tempat dan waktu. Berkenaan dengan itu Protagoras pernah mengemukakan bahwa tiap manusia adalah ukuran bagi segala sesuatu.

Atas dasar pemikiran itulah maka kaum Pluralis menempatkannya untuk mencari jalan keluar atas persoalan hubungan antara agama-agama dengan titik tolak relativisme. Ernst Troelstch yang merupakan tokoh peletak Pluralisme modern, memulai refleksi teologisnya dengan berupaya mengatasi konflik besar antara relativisme historis dan kemutlakan kristiani. Titik pijak awalnya dari pemahaman bagaimana Allah menyatakan dirinya dalam sejarah manusia. Ia menawarkan suatu bentuk metafisika tradisi yang imanen. Bagi Troeltsch, ia berusaha membuat sintesis antara relativisme historis dan absolutisme religius. "Masalah yang dihadapi oleh pendekatan sejarah bukanlah bagaimana membuat sebuah pilihan ini atau itu antara relativisme dan absolutisme, namun bagaimana menggabungkan keduanya."19

Ketika kerangka epistimologi ini dikenakan dalam perbincangan pluralitas agama, maka jelas bagi Troeltsch bahwa semua agama didunia ini bersifat relatif. Manusia yang beragama adalah makhluk historis, yang dapat mengalami sesuatu dan hidup dalam proses sejarah tertentu.

${ }^{18}$ Ibid. hlm. 201.

${ }^{19}$ Horald Coward, Pluralisme Tantangan bagi Agama-agama, (Yogyakarta: Penerbit Kanisius, 1989), hlm. 60. 
Agama merupakan sarana dimana manusia mengalami kehadiran Allah secara imanen dan setiap agama memiliki karakter yang sama yaitu pengalaman akan pernyataan Allah yang transeden dalam sejarah imanen. Dengan demikian agama sebagai suatu bentuk manifestasi yang absolut tidak bisa menjadi absolut karena keterikatan sejarahnya. Troeltsch ingin mengemukakan bahwa yang absolut itu yang merelativir sejarah bukannya sejarah merelativir yang absolut. Dia juga tetap mengemukakan kesadaran bahwa dalam proses menyejarah itu, setiap agama memiliki tujuan yang sama, yaitu menuju pemenuhan yang absolut itu. Namun, dalam perjalanan menuju sejarah akhir itu, setiap agama dipandang sebagai relatif.

Tokoh lain yaitu Arnold Toynbee mengatakan bahwa semua agama sementara mempertahankan identitas historis masing-masing, akan menjadi lebih terbuka pikirannya terhadap satu agama dengan yang lainnya sebagaimana warisan-warisan spiritual dan kultur dunia yang berbeda-beda, makin menjadi kepunyaan bersama umat manusia. Relativisme seperti itulah yang akhirnya menjadi api yang membakar semangat kaum Pluralis dalam berdialog dengan kaum inklusif, dan membuang finalitas Yesus. Pluralis India Stanley Samartha berpendapat, "Semua pendekatan orang Kristen terhadap agama lain adalah berdasarkan pada suatu teori kekristenan yang tanpa nama atau kristologi kosmik orang Kristen tidak boleh melupakan bahwa dalam inkarnasi Allah merelatifkan dirinya." ${ }^{20}$

Seorang tokoh lain yang merupakan peletak dasar Pluralisme yaitu John Hick, meletakkan relativisme yang lebih dalam dari Troeltsch. Ia mengatakan iman berpusat pada Allah dan bukan pada kekristenan atau agama lain, yang merefleksikannya dengan cara-cara mereka sendiri secara berbeda. Dalam teori revolusi Copernicus ia menambahkan, "Dan revolusi Copernicus yang dibutuhkan dalam teologi melibatkan sebuah transformasi yang secara radikal

${ }^{20}$ Ibid. 
setara dalam konsepsi kita mengenai semesta iman dan tempat agama kita sendiri didalamnya. Hal itu melibatkan sebuah transformasi yang secara radikal setara dalam konsepsi kita mengenai semesta iman dan tempat agama kita sendiri didalamnya. Hal itu melibatkan sebuah pergeseran dari dogma bahwa kekristenan berada di pusat kesadaran bahwa Allahlah yang berada dipusat, dan bahwa semua agama manusia, termasuk agama kita, melayani dan berkisar disekelilingnya."21

Dibagian lain ia menambahkan dengan membedakan tiga komponen dari persoalan teologis yang muncul. Ia berkata, "Kita dapat membedakan tiga jenis perbedaan dan konflik diantara agama-agama dunia; perbedaan dalam cara mereka mengalami kenyataan ilahi; perbedaan dalam peristiwa-peristiwa kunci atau terwahyukan yang kepadanya aliran pengalaman keagamaan yang berbeda menemukan asal muasal mereka dan dengan memakainya mereka memusatkan ibadah mereka."22

Dari pernyataan-pernyataan diatas maka dapat diambil suatu kesimpulan bahwa relativisme adalah salah satu titik tolak yang dipakai oleh kaum Pluralis sebagai salah satu dasar dalam meletakkan pandangan mereka.

Perubahan dari Modernisme ke Postmodernisme: Pergeseran Paradigma Eksklusivisme ke Pluralisme

Friedriech Nietzsche adalah salah satu tokoh yang berperan penting dalam era postmodernisme. Ia adalah orang yang mempunyai sikap sangat kritis terhadap roh Absolut Hegel. Michel Foulcault adalah seorang yang sangat dipengaruhi oleh pemikiran Nietzsche pada akhir 1950-an dan ia mulai bersikap kritis terhadap historisisme dan humanisme. Penulis yang lain yang juga gencar dalam mempromosikan postmodernisme, Jean Francois Lyotard juga beralih ke

\footnotetext{
${ }^{21}$ Ibid, hlm. 61.

${ }^{22}$ Ibid. hlm. 62.
} 
pemikiran Nietzsche. Jaccques Derrida pun terus-menerus mengutip Nietzsche dalam tulisantulisannya. Atau juga seorang pemikir postmodern lainnya, Gilles Deleuze, menyatakan bahwa Nietzsche adalah kritikus utama pemikiran dialektis Hegel. Semangat postmodernisme ini akhirnya merambat kesegala bidang keilmuan dan kehidupan masyarakat, termasuk pula teologi. ${ }^{23}$

Akhirnya ide pluralitas dan relativis makna ini mulai diperluas, bukan hanya dalam diskursus mengenai wacana yang suci namun juga tentang Allah sendiri, yang akhirnya membawa kepada teologis yang lebih besar bagi teologia religionum, yang mengacu kepada relativis. Paul F. Knitter seperti yang dikemukakan AK Craggs pun mulai menjelaskan keunikan Kristus tersebut sebagai "sebuah keunikan rasional". Yang akhirnya mengakui kebenaran yang diyakini orang Kristen bersifat relatif ditengah arena agama-agama lain, yang menurut mereka tidak serta merta berarti mengabaikan keunikan kebenaran tersebut, namun sebaliknya mengakui keunikan tersebut dalam relasi dengan orang lain. ${ }^{24}$

Kelompok postmodernisme juga selalu mengemukakan tiga paradigma teologi religionum, yaitu eksklusivisme, inklusivisme dan pluralisme. Pergeseran itu sendiri adalah akibat pergerakan pemikiran yang menyimpang dari Alkitab. Inklusivisme muncul dengan sebuah penolakan konsep eksklusivisme yang terutama dipegang oleh orang-orang Fundamentalisme yang menekankan tentang keselamatan satu-satunya didalam Kristus Yesus. Inklusivisme muncul dengan ide baru yaitu dengan menawarkan konsep universalitas kasih Allah bagi agama-agama lain. Allah diyakini mengerjakan keselamatan dalam agama-agama lain, walau tidak lengkap dan justru dipenuhi oleh Kristus sendiri. Hal ini dimunculkan oleh para kaum inklusivis karena menurut mereka sikap eksklusivis merupakan hal yang negatif bagi agama lain, karena sikap ini

\footnotetext{
${ }^{23}$ Ali Maksum, Pengantar Filsafat: Dari Masa Kalsik hingga Postmodernisme, (Jogjakarta: AR-RUZZ MEDIA, 2008), hlm. 315-332.

${ }^{24}$ Paul F. Knitter, Satu Bumi Banyak Agama, terj: Noco A. Likumahua, (Jakarta: BPK Gunung Mulia, 2015), hlm. 12.
} 
kurang memberi tempat pemahaman aktual agama-agama lain. Namun kehadiran Inklusive ini sendiripun dianggap tidak memadai oleh para Pluralis. Mereka mengatakan bahwa paradigma ini dapat terjebak dalam suatu imperialisme teologis dan menyimpan suatu sikap tak jujur dan tak menghargai entitas agama lain, sebagaimana mereka alami dan hayati. Oleh sebab itu kelompok Pluralis menawarkan sesuatu yang baru. Mereka menawarkan konsep relativitas, yang ditekankan pada universalitas kasih Allah yang lebih luas bagi dunia. Pluralisme menekankan teosentrisme, yaitu menekankan bahwa semua agama-agama memusatkan diri kepada Allah dan Kristus bukanlah satu-satunya jalan keselamatan.

\section{Masalah Kemajemukan dan Dialog Agama}

Salah satu faktor lain yang menghasilkan konsep Pluralisme adalah masalah kemajemukan agama. Fakta tentang keberagaman agama dan kemajemukannya adalah satu hal yang tidak bisa dipungkiri oleh siapapun juga. Dan secara otomatis tiap-tiap agamapun akan bersentuhan dengan agama-agama yang lain. Hans Kung seorang teolog Katolik yang radikal dalam tulisan Pinnock mengemukakan, "Untuk pertama kali dalam sejarah dunia adalah sesuatu yang mustahil bagi satu agama untuk eksis dalam isolasi yang sangat baik dan mengabaikan yang lain.” Kesadaran akan kemajemukan itu tidak hanya sampai pada tingkat mengalami keberadaan agama lain, tetapi juga dituntut untuk membangun hubungan yang baik dan toleransi yang lebih luas. Maka tak terhindarkan lagi seruan-seruan untuk dialog dan membuka hubungan yang lebih luas mulai diperdengungkan.

Masuknya agama lain itu memberi corak yang beragam bagi suatu bangsa atau negara. Imigran dari negara-negara, membawa serta agama-agama baru ke negara yang ditempati. Khususnya negara-negara maju akan menjadi tujuan dari negara-negara yang miskin dan 
terbelakang. Contohnya saja Amerika yang menjadi tempat imigran dari warga negara lain yang masih terkebelakang dan miskin. Di situlah muncul agama-agama orang imigran masuk ke satu negara tertentu sehingga terjadi kemajemukan agama.

Kemajemukan itu sendiri oleh karena klaim-klaim keabsolutan akhirnya mau tidak mau akan saling berbenturan satu dengan yang lain, dan hal itu bukanlah sesuatu yang mudah untuk dihadapi. Indonesia sendiri yang mempunyai keragaman agama telah sering kali mengalami hal yang tragis yang berhubungan dengan hal itu. Toleransi agama yang ada tidak cukup lagi bagi pemikiran sebagian orang, apalagi setiap agama masing-masing punya misi yang tersendiri. Akhirnya berbagai dialog semakin gencar dilakukan, apalagi dengan adanya konflik membuat masing-masing pemimpin agama bersatu dan bukan lagi hanya sekedar dialog tetapi juga akhirnya mencapai doa bersama. ${ }^{25}$

Menyadari hal itu akhirnya kaum Pluralis mulai mengembangkan sistem theologia mereka. Paul Knitter, salah satu penggagas utama Pluralisme mengemukakan, "Suatu model pluralistis menggambarkan perubahan baru-apa yang disebut sebagai "pergeseran paradigma" dalam usaha teolog Kristen, baik dimasa lalu maupun sekarang, untuk memahami dunia berbagai agama lain dan tempat agama Kristen dalam dunia tersebut. Suatu pergeseran paradigma mewakili perubahan yang sungguh-sungguh berbeda, namun juga tergantung pada apa yang hadir sebelumnya." Lebih lanjut ia menambahkan, "Dengan argumentasi ancaman awan jamur memaksa semua agama untuk berdialog dan bekerjasama, Kaufman (salah satu tokoh Pluralis juga-penulis)sebagai syarat yang perlu untuk dialog semacam itu- mengusulkan agar para pemeluk agama

\footnotetext{
${ }^{25}$ A.A. Yewangoe, Agama dan Kerukunan, (Jakarta: BPK Gunung Mulia, 2011), hlm.43-44.
} 
mengakui relativitas historis semua bentuk keagamaan dan dengan demikian meninggalkan klaimklaim masa lalu tentang bentuk agama "satu-satunya" atau bentuk yang "tertinggi". ${ }^{26}$

Sementara itu tiga orang teolog Pluralis Asia yaitu Raimundo Panikkar, Stanley Samartha, dan Choan Seng Song adalah orang yang menyetujui konsep dialog sebagai misi utama semua agama, terutama kekristenan. Mereka mendefinisikan pendekatan mereka yang dialogis ialah," membiarkan pembahasan teologi kita dipengaruhi teologi agama lain, sehingga kita terpaksa makin jujur dan lebih memperdalam rohani kita. Song dan Panikkar setuju bahwa dialog adalah,"perjumpaan yang sejati dengan orang lain kepercayaan dan ideologi lain dan menemukan bahwa ada jalan lain untuk mengenal kebenaran dari pada yang kita telah pelajari." Dan Song mengusulkan adanya pertobatan dialogis, yaitu: "berbalik dari memakai dialog sebagai alat untuk mengubah iman kepercayaan lain dan melangkah masuk kedalam kehidupan mitra-mitra dialog." Stanley Samartha berpendapat bahwa, "Seorang Kristen harus mendekati dialog atas dasar Teosentris dan bukan atas dasar Kristosentris. Hal ini membebaskan orang Kristen dari anggapan diri sebagai pemilik wahyu dan kebenaran satu-satunya." Ia mempermasalahkan sikap terbukanya orang Kristen yang bersifat netral. Dengan dasar konsep inkarnasi, ia mendorong supaya orang Kristen untuk berani berdialog. Karena itu ia mengartikan bahwa dialog adalah, "Upaya untuk memahami dan menyatakan partikularitas kita bukan hanya dalam kaitan dengan warisan kita sendiri tetapi juga dalam hubungan dengan warisan rohani tetangga-tetangga." Sedangkan Raimundo Panikkar meyatakan bahwa, "melalui dialog-dialog pengalaman-pengalaman partikular mengenai kebenaran-Kristus bagi orang Kristen, Veda bagi orang Hindu dapat diperluas dan diperdalam sehingga menyingkap pengalaman-pengalaman partikular mengenai kebenaran. Melalui dialog akan terjadi perluasan dan pendalaman setiap pengalaman partikular mengenai

\footnotetext{
${ }^{26}$ Paul F. Knitter, Satu Bumi Banyak Agama, terj: Noco A. Likumahua, (Jakarta: BPK Gunung Mulia, 2015), hlm. 51-52.
} 
kebenaran ilahi." Song menyetujui bahwa dialog ialah, "perjumpaan yang sejati dengan orang lain kepercayaan dan ideologi lain dan menemukan bahwa ada jalan lain untuk mengenal kebenaran daripada yang telah kita pelajari."${ }^{27}$

\section{Pergeseran Pandangan Teologi Katolik Roma dan Dewan Gereja Dunia}

\section{Pergeseran Pandangan Teologi Katolik Roma}

Munculnya Pluralisme terlebih dahulu dipelopori oleh teolog Roma. Dan Pluralisme dalam teolog Protestan banyak dipacu oleh semangat perubahan yang terjadi dalam pemikiran cendekiawan Katolik. Perubahan pikiran yang terjadi dalam doktrin-doktrin Katolik sendiripun terjadi karena munculnya teolog-teolog Katolik dengan ide-ide dan pemikiran yang baru. Mereka diantara yang paling terkemuka adalah Karl Rahner, Hans Kung, Raimundo Panikkar, Stanley Samartha dan Paul F. Knitter. ${ }^{28}$

Perubahan itu sendiri sangat nampak setelah Konsili Vatikan II. Konsili Vatikan II adalah perubahan paradigma teologi Katolik. Salah satu yang menjadi motor perubahan tersebut adalah Karl Rahner. Dan salah satu sumbangannya yang paling besar bagi teologia religionum Katolik secara khusus muncul pada volume ke 5, dalam esai yang berjudul, "Kekristenan dan Agamaagama non Kristen." Melalui esai yang ditulis dalam Theological Investigation (Vol.5) ia menyodorkan empat tesis yang terkenal yang secara khusus membahas tentang "Anonymous Christians", yaitu orang-orang yang diselamatkan karena kasih karunia Kristus yang sekalipun tanpa disadari oleh mereka dan merekalah orang Kristen tanpa nama. ${ }^{29}$

\footnotetext{
27 Ibid.

${ }^{28}$ Horald Coward, Pluralisme Tantangan, ... . hlm. 79.

${ }^{29}$ Ibid, hlm 71.
} 
Ia menjelaskan bahwa keselamatan terjadi bukan karena manusia yang merespon, namun karena Allah didalam Kristuslah yang menyelamatkan. Ia mendasarkan pandangannya atas 1 Timotius 2:3-4, mengindikasikan bahwa semua orang mendapat kesempatan untuk percaya, suatu kesempatan yang historis bukan abstrak yang teoritis. Melalui kasih karunia Allah yang bekerja pada tiap manusia sampai pada saat ia dihadapkan pada Injil Kristen, kasih karunia Allah didalam Yesus Kristus dapat menjangkau manusia melalui agama yang bukan Kristen bahkan termasuk juga atheis. Menurut Rahner pengalaman masing-masing orang yang "transeden" yakni "rahasia mutlak" adalah pengalaman tentang Allah.

"Orang yang menerima bahwa suatu tuntutan moral dari hati nuraninya adalah mutlak sah baginya dan menerimanya sebagai sesuatu yang sah dalam suatu pengakuan yang diberinya secara bebas-betapapun secara spontan- ia menegaskan adanya Allah secara mutlak, terlepas dari apakah ia tahu atau mengertinya, sebagai sebab adanya hal itu seperti tuntutan moral yang mutlak." 30

Sementara itu Hans Kung juga memberikan sumbangan yang besar terhadap pemikiran teologia Katolik. Ia mengatakan 2 hal penting. Pertama dilihat dari luar, berdasarkan kriteria etis dan religius, terdapat bermacam-macam agama yang benar. Setiap agama merupakan jejak keselamatan menuju satu tujuan. Kedua, jika dilihat dari dalam, dari sudut pandang kekristenan, maka agama Kristen yang berorientasi pada Kristus yang disaksikan Alkitab merupakan agama yang benar.

Gereja Katolik tak menolak apapun yang benar dan kudus dalam agama-agama ini. Ia menyikapi dengan rasa hormat yang tulus jalan-jalan prilaku dan kehidupan ini, aturan-aturan dan ajaran-ajaran yang sekalipun berbeda dalam banyak segi dari yang dipegang dan diteruskan oleh Gereja, namun kerap memantulkan sinar Kebenaran yang menerangi semua manusia.

\footnotetext{
${ }^{30}$ Nico Syukur Dister, Filsafat Agama Kristen, (Yogyakarta: Penerbit Kanisius, BPK Gunung Mulia, 1989), hlm. 27.
} 
Dokumen lain yang diresmikan dalam konsili, "Konstitusi Dogmatis mengenai Gereja." Yang menjelaskan pula kemungkinan setiap manusia dalam agama mereka masing-masing untuk menerima keselamatan sehubungan dengan tiadanya kesempatan menerima berita Injil.

Mereka yang... tidak mengenal injil Kristus atau Gerejanya, namun yang mencari Allah dengan hati tulus dan tergerak oleh anugrah mencoba dalam tindakan mereka untuk melakukan kehendakNya selama mereka mengenalnya melalui suara hati mereka-mereka juga dapat memperoleh keselamatan kekal. ${ }^{31}$

Dibagian lain juga dituliskan:

[Penyelamatan] bukan hanya untuk orang Kristen, tetapi untuk semua orang yang berkehendak baik, yang didalam hatinya kasih karunia bekerja dengan cara yang tidak kelihatan. Sebab, karena Kristus mati untuk semua orang, dan kerena panggilanpokok manusia sebenarnya satu dan ilahi, maka kita harus percaya bahwa Roh Kudus dengan cara yang hanya diketahui oleh Allah, menawarkan kepada setiap orang kemungkinan untuk berhubungan dengan rahasia paskah ini. ${ }^{32}$

Dengan demikian jelaslah terjadi perubahan yang sangat signifikan dari gereja Katolik dengan paham "diluar gereja tidak ada keselamatan" (yang eksklusif) menjadi inklusif dalam konsili Vatikan II ini dan akhirnya menjadi kearah Pluralisme.

\section{Sidang Raya Dewan Gereja Dunia}

Perubahan yang paling mendasar dan mendukung perkembangan Pluralisme terjadi pada sidang Dewan Gereja Dunia di Uppsala (1968) dengan tema: Lihatlah Aku Menjadikan Segala Sesuatu Baru! Yang paling penting dan kontroversial adalah Pembaruan Dalam Misi. Pada sidang sebelumnya mereka masih menekankan perlunya memberitakan Injil kepada non Kristen tetapi pada sidang ini hampir tidak disinggung, sebaliknya menekankan pada dimensi "horisontal", yaitu perdamaian pada umat manusia. Sidang di Uppsala menjadi titik tolak perjumpaan dengan agamaagama lain di dunia bahwa:

\footnotetext{
${ }^{31}$ Knitter, Satu Bumi . . . , hlm. 182.

${ }^{32} \mathrm{Ibid}$, hlm. 183.
} 
Pertemuan dengan orang-orang yang berbeda keyakinan atau orang-orang tidak beriman harus memimpin kepada dialog. Dialog Kristen dengan orang tidak seiman menunjukkan bukan suatu penyangkalan mengenai keunikan Yesus dan bukan meniadakan komitmennya sendiri kepada Yesus. Tetapi pendekatan orang Kristen kepada orang yang tidak seiman harus manusiawi, bersifat pribadi, relevan dan rendah hati. Dalam dialog, kita membagi rasa kemanusiaan kita, baik harkat martabatnya dan kejatuhannya, serta mengekspresikan kepedulian kita untuk kemanusiaan.Masing-masing bertemu dan menantang yang lain, bersaksi dari kedalaman keberadaannya kepada kepedulian yang tinggi yang mendatangkan perwujudan perkataan dan perbuatan. Sebagai orang Kristen kita percaya bahwa Kristus berbicara dalam bentuk dialog, menyatakan diri-Nya kepada mereka yang tidak mengenal Dia dan mengkoreksi pengetahuan mereka yang terbatas dan kabur. Dialog dan proklamasi Injil adalah berbeda, tetapi kadang-kadang orang Kristen tidak dapat menempatkan dalam pembukaan dialog dan proklamasi Injil. ${ }^{33}$

Walaupun banyak pertentangan-pertentangan yang terjadi di sidang Uppsala terutama dari kelompok Injili, namun kaum Pluralis mengambil keuntungan dengan konsep yang lebih luas dalam pandangan teologia mereka. Sidang Uppsala merupakan dasar bagi dukungan teologi bagi mereka. Salah satu teolog Asia C.S. Song mendefinisikan misi Kristennya yang pluralis bertolak dari rumusan Sidang Raya Dewan Gereja Dunia kelima di Nairobi, perkembangan dari Uppsala. Ia menekankan bahwa misi berarti mencari persekutuan dengan orang lain dalam kasih Allah.

\section{Catatan Analisis}

Sepanjang sejarah keagamaan, pluralis ini selalu muncul diagama yang bersumber pada agama Semetik maupun di bangsa-bangsa lain. Di sinilah dipenting hikmat bijaksana untuk

${ }^{33}$ Olaf H. Schumann, Dialog Antarumat Beragama, (Jakarta: BPK Gunung Mulia, 2009), hlm. 474-475. 
menghidupi suatu keyakinan sehingga kerukunan dan kebersamaan itu dapat terwujud dengan baik. Tanpa kerukunan dan kebersamaan menjadikan umat manusia dalam suatu kelompok akan terjadi congkrah dan peperangan yang sangat merugikan dan menghancurkan umat manusia.

Jalan dialog akkhir-akhir ini yang dipakai oleh golongan keagamaan untuk mewujudkan kerukunan, walaupun hal ini tidak mutlak benar. Namun hal ini (dialog) dapat sedikit meredam pertikaian, walaupun hal itu bersifat sementara. Sering terjadi ketidakpuasan dalam dialog ini karena terjadi ketidakadilan, kaum minoritas cendurung dikalahkan dan keuntungan ada pada pihak yang kuat. Dialog ini dipakai oleh kaum Kristiani karena masih ada titik-titik kecil atau yang bernilai untuk menyaksikan tentang "kabar baik/Injil" bagi mereka. Masalah penerimaan kabar baik itu adalah urusan dari pada Roh Kudus.

Pluralisme ini umumnya dipegang kuat oleh kelompok ekumenis yang dalam teologinya menekankan kehidupan kemanusiaan selama ia diberi kesempatan hidup. Kaum Injili cenderung menekankan pentingnya keselamatan jiwa yang hanya diperoleh melalui karya Kristus. Pastilah kaum injili ini sangat berhati-hati dalam mensikapi pluralisme ini karena mendasarkan pada keyakinannya yang sangat esensiil.

Harus diingat bahwa pluralisme yang diterima oleh setiap agama: Islam, Kristen, Hindu, Buddha, yang memiliki bahwa keyakinan masing-masing agama ada keselamatan dan masingmasing agama dipakai oleh Allah untuk mengajarkan keselamatan pada bangsanya. Penerimaan pluralisme dari agama-agama ini di dasarkan atas kebenaran yang ada dalam setiap agama, namun yang paling dapat menyelamatkan adalah agama dan keyakinan yang dipeluknya. 


\section{DAFTAR PUSTAKA}

Tuhan Yesus memang Khas Unik. terj: Lilian Tedjasudhana. Jakarta: Yayasan Komunikasi Bina Kasih/OMF, tt

Banawiratma, J.B., dkk. Hak Asasi Manusia Tantangan bagi Agama. Yogyakarta: Kanisius, 1999.

Coward, Horald. Pluralisme Tantangan bagi Agama-agama. Yogyakarta: Penerbit Kanisius, 1989.

D’Costa, Cavin (penyunting). Mempertimbangkan Kembali Keunikan Agama Kristen. Jakarta: BPK Gunung Mulia, 2009.

Dister, Nico Syukur. Filsafat Agama Kristen, Yogyakarta: Penerbit Kanisius, BPK Gunung Mulia, 1989.

Enns, Paul. The Moody Handbook of Theology, terj: Rahmiati Tanudjaja. Malang: Literatur SAAT, 2007.

Knitter, Paul F. Satu Bumi Banyak Agama, terj: Noco A. Likumahua.Jakarta: BPK Gunung Mulia, 2015.

Maksum, Ali. Pengantar Filsafat: Dari Masa Kalsik hingga Postmodernisme. Jogjakarta: ARRUZZ MEDIA, 2008.

Schumann, Olaf H. Dialog Antarumat Beragama, Jakarta: BPK Gunung Mulia, 2009.

Smith, Linda dan William Raeper. Ide-ide Filsafat dan Agama Dulu dan Sekarang. Yogyakarta: Penerbit Kanisius, 2000.

Yewangoe, A.A. Agama dan Kerukunan. Jakarta: BPK Gunung Mulia, 2011. 
24 Jurnal Te ologi S A C T UM D O M I N E 